Didaktik : Jurnal Pendidikan Guru Sekolah Dasar, ISSN : 24775673

Sekolah Tinggi Keguruan dan IImu Pendidikan Subang

Volume IV Nomor 2, Desember 2018

\title{
PENGARUH KEMAMPUAN DAN PERILAKU GURU TERHADAP KUALITAS PELAYANAN PENDIDIKAN
}

\author{
Ipong Dekawati \\ Pascasarjana Universitas Wiralodra \\ ipongdekawati@unwir.ac.id
}

\begin{abstract}
This research has been carried out and analyzed by taking the main focus on the ability and behavior of teachers and their impact on the quality of education services. The method used is the explanatory survey method where the author went directly to the empirical level by spreading the questionnaire to 40 teachers at the State Elementary School. The technique of processing and analysis used is regression. The results showed that: (1) There is a positive and significant influence ability of teachers on the quality of education services at the State Elementary School. The amount of influence of the teacher's ability on the quality of education service is $32.1 \%$.

(2) There is a positive but less significant effect of teacher behavior on the quality of education service at the State Elementary School. The amount of influence of teacher behavior on the quality of education service is 3.7\%. (3) There is a positive and significant influence teacher's ability and teacher's behavior together towards the quality of education service. The amount of influence of teacher ability and teacher behavior simultaneously on the quality of education service is $32,6 \%$. Moving from the conclusion of the research that has been stated above, humbly the writer suggest that: (1) The result of research has shown that operationally both teacher ability and teacher behavior and quality of education service have been quite good. But as the development of community demands in the future it should not be satisfied until the present condition. It is recommended that the principal together with the teacher continue to improve the quality of education services in a sustainable manner with the development of teachers through participation in scientific forums so that the knowledge, insight and ability of teachers can keep abreast of developments. (2) It can be proved that both the ability and behavior of teachers affect the quality of education services. Therefore, to always maintain or improve the quality of education services that can be started by improving the ability and behavior of teachers through special attention to the needs and desires of consumers.
\end{abstract}

Keywords: Teacher Ability, Teacher Behavior, Quality of Education Service

\section{ABSTRAK}

Penelitian ini telah dilaksanakan dan dianalisis dengan mengambil fokus utama pada kemampuan dan perilaku guru serta pengaruhnya terhadap kualitas pelayanan pendidikan. Metode yang digunakan adalah metode 
survey di mana penulis terjun langsung ke tataran empirik dengan menyebarkan angket terhadap 40 orang guru pada SD Negeri. Teknik pengolahan dan analisis yang digunakan adalah regresi. Hasil penelitian menunjukkan bahwa: (1) Terdapat pengaruh yang positif dan signifikan kemampuan guru terhadap kualitas pelayanan pendidikan pada SD Negeri. Besarnya pengaruh kemampuan guru terhadap kualitas pelayanan pendidikan adalah $32,1 \%$. (2) Terdapat pengaruh yang positif tetapi kurang signifikan perilaku guru terhadap kualitas pelayanan pendidikan pada SD Negeri. Besarnya pengaruh perilaku guru terhadap kualitas pelayanan pendidikan adalah 3,7 \%. (3) Terdapat pengaruh yang positif dan signifikan kemampuan guru dan perilaku guru secara bersama-sama terhadap kualitas pelayanan pendidikan pada SD Negeri. Besarnya pengaruh kemampuan guru dan perilaku guru secara simultan terhadap kualitas pelayanan pendidikan adalah 32,6 \%. Beranjak dari kesimpulan hasil penelitian yang telah dikemukakan di atas, maka dengan rendah hati penulis menyarankan, bahwa: (1) Hasil penelitian telah menunjukkan bahwa secara operasional baik kemampuan guru maupun perilaku guru dan kualitas pelayanan pendidikan sudah tergolong cukup baik. Tetapi seiring pengembangan tuntutan masyarakat ke depan maka sebaiknya tidak puas sampai pada kondisi sekarang. Sebaiknya kepala sekolah bersama-sama dengan guru terus meningkatkan kualitas pelayanan pendidikan secara berkelanjutan dengan pengembangan guru melalui kesertaan pada forum ilmiah agar pengetahuan, wawasan dan kemampuan guru terus dapat mengikuti perkembangan. (2) Telah dapat dibuktikan bahwa baik kemampuan maupun perilaku guru berpengaruh terhadap kualitas pelayanan pendidikan, sekalipun kurang signifikan. Oleh karena itu, untuk selalu mempertahankan atau meningkatkan kualitas pelayanan pendidikan yang dapat dimulai dengan meningkatkan kememampuan dan perilaku guru melalui perhatian khusus terhadap kebutuhan dan keinginan konsumen.

\section{Kata Kunci: Kemampuan Guru, Perilaku Guru, Kualitas Pelayanan Pendidikan}

\section{A. Pendahuluan}

Pelayanan

pendidikan

merupakan pelayanan dasar yang wajib disediakan oleh pemerintah dalam rangka meningkatkan kualitas sumber daya manusia (SDM). Pelayanan pendidikan juga merupakan salah satu indikator keberhasilan pembangunan sumber daya manusia, pendidikan memegang peranan strategis dalam rangka meningkatkan derajat kehidupan masyarakat. Untuk itu pemerintah kuhusnya pemerinrah daerah perlu melakukan perencanaan, pembangun-an dan pembinaan terhadap pendidikan secara komprehensif dan berkesinam-bungan.

Dewasa ini lembaga pendidikan dalam menjalankan tugas pelayanan pendidikan sudah banyak yang bagus terutama di kota-kota besar. Tetapi dalam beberapa satuan pendidikan pelayanannya masih belum sesuai harapan. Secara 
umum masih terdapat kelemahan yang dapat diamati, antara lain: (1) Belum handalnya tenaga pendidik yang disebabkan oleh sebaran kemajuan masyarakat Indonesia dari segi ilmu pengetahuan termasuk masalahah keberadaan pendidik yang handal sangat tidak merata; (2) Karena kesibukkan internal masih dijumpai pendidik dan tenaga kependidikan kurang responsif terhadap masyarakat pengguna yaitu orang tua peserta didik; (3) Masih dijumpai elemen masyarakat yang belum yakin akan kemampuan institusi pendidikan dalam melaksana- kan proses pembelajaran. Baik kurang yakin oleh karena sumber daya manusianya maupun fasilitas dan perlengkapannya; (4) Kurangnya empati dari pihak sekolah terhadap peserta didik yang mengalami permasalahan dalam mengikuti pembelajaran; (5) Unsur-unsur pelayanan yang terlihat atau terasa langsung oleh para pengguna jasa pendidikan masih kurang terperhatikan. Misalnya saja: lingkungan sekolah tidak rapi, toilet kurang bersih, pakaian seragam guru kurang menggambarkan kerapian seprang pendidik.

Untuk memenuhi kebutuhan dan tantangan pembangunan pendidikan, sejalan dengan otonomi daerah, pemerintah daerah wajib mengembang-kan kebijakan untuk meningkatkan kualitas pelayanan pendidikan. Tenaga Pendidik dan kependidikan di daerah perlu pengembangan terus untuk meningkatkan profesionalismenya sehingga mampu menjawab kebutuhan masyarakat. Peningkatan kualitas sumber daya manusia melalui pendidikan atau pelatihan adalah salah satu upaya untuk meningkatkan kualitas sumber daya manusia agar terus dikembangkan. Untuk meningkatkan kualifikasi pegawai dalam hal ini pendidik dan tenaga kependidikan sesuai dengan tuntutan masyarakat. Siagian (2002:179) telah menegaskan "pentingnya pembinaan kualitas sumber daya pegawai yang dianggap memegang posisi sentral dalam organisasi birokrasi. Pembinaan sumberdaya pegawai mencakup faktor-faktor kualifikasi, keterampilan, jumlah, kemampuan pelaksanaan tugas dan masa kerja."

Salah satu faktor penting untuk diperhatikan karena diduga kuat memiliki pengaruh terhadap kualitas pelayanan pendidikan adalah perilaku serta kemampuan guru dan tanaga kependidikan lainnya yang kadang-kadang pengaruh birokrasi pada instansi lain terbawa ke satuan pendidikan. Kemapuan guru menyangkut bagaimana tingkat keahlian dan liniertasnya dalam mengemban tugas sebagai guru. Sebab sekalipun pendidikan guru telah memenuhi standar strata 1 , apabila mengajarnya tidak linier dengan latar belakang pendidikannya menjadi kurang memadai kemampuannya. Guru juga harus terampil dalam memberikan contoh terutama yang berkaitan dengan mata pelajaran yang ada prakteknya. Guru yang ideal juga atau dianggap kemampuannya istimewa adalah guru yang berpengalaman. Serta guru yang dianggap mampu adalah guru yang memiliki sikap mental yang dapat diteladani.

Keputusan Menteri Pendayaguna- an Aparatur Negara Nomor 81 Tahun 1993 yang 
kemudian disempurnakan dengan keputusan Menteri Pendayagu- naan Aparatur Negara Nomor 63 Tahun 2004 mendifinisikan pelayanan publik adalah segala kegiatan pelayanan yang dilaksanakan oleh penyelenggara pelayanan publik sebagai upaya pemenuhan kebutuhan penerima layanan maupun pelaksanaan ketentuan peraturan perundang-undangan. Secara lengkap adalah bahwa "segala bentuk pelayanan yang dilaksanakan oleh instansi pemerintah di pusat, di daerah, dan lingkungan Badan Usaha Milik Negara atau Badan Usaha Milik Daerah dalam bentuk barang atau jasa, baik dalam rangka upaya pemenuhan kebutuhan masyarakat maupun dalam rangka pelaksanaan ketentuan peraturan perundangundangan" (Kepmenpan Nomor 63/2004).

Secara lebih eksplisit dinyatakan oleh Sianipar (2001:5) pelayanan publik dapat dinyatakan sebagai segala sesuatu bentuk pelayanan sektor publik yang dilaksanakan pegawai pemerintah dalam bentuk barang dan jasa, yang sesuai dengan kebutuhan masyarakat dan ketentuan peraturan perundangundangan yang berlaku. Sejalan dengan pendapat di atas maka Senge (2001:25) mengatakan "public service generally means services rendered by the public sector-the state or government". Pernyataan ini dilandasi suatu pemikiran bahwa kekuasaan dan wewenang yang dimiliki pemerintah bersumber dari rakyat, sehingga maju atau mundurnya, kuat atau lemahnya suatu pemerintahan ditentukan oleh rakyat. Karena pentingnya dukungan rakyat ini pulalah maka pemerintah harus berupaya memberikan pelayanan yang baik kepada mereka.

Sejalan dengan pelaksanaan otonomi daerah, maka pada hakekat- nya pemerintah harus mampu menyediakan pelayanan publik sesuai dengan kebutuhan masyarakat. Hal ini sesuai dengan fungsi utama dari pemerintah daerah yaitu memberikan kesejahteraan masyarakatnya. Tingkat kesejahtaraan masyarakat akan sangat tergantung pada pelayanan publik yang prima (service excellence) yang dilaksanakan oleh pemerintah daerah.

Zeithaml, et al (2002:26), menjelaskan dimensi kualitas pelayanan yang dinyatakan dengan SERVQUAL Dimensions, yaitu: (1) Tangibles (kualitas pelayanan yang berupa sarana fisik perkantoran, komputerisasi administrasi, ruang tunggu, tempat informasi, dan sebagainya); (2) Reliability (kemampuan dan keandalan untuk menyediakan pelayanan yang terpercaya); (3) Responsiveness (kesanggupan untuk membantu dan menyediakan pelayanan secara cepat dan tepat, serta tanggap terhadap keinginan konsumen); (4) Assurance (kemampuan dan keramahan, serta sopan santun pegawai dalam meyakinkan kepercayaan konsumen); Emphaty sikap tegas tetapi penuh perhatian dari pegawai terhadap konsumen)

Mulyasa (2003:38), mengadopsi pendapat McAhsan (2002:45), mengemukakan bahwa kompetensi: “...is a knowledge, skills, and abilities or capabilities that a person achieves, which become part of his or her being to the extent he or she 
can satisfactorily perform particular cognitive, affective, and psychomotor behaviors". Dalam hal ini, kompetensi diartikan sebagai pengetahuan, keterampilan, dan kemampuan yang dikuasai oleh seseorang yang telah menjadi bagian dari dirinya, sehingga ia dapat melakukan perilaku-perilaku kognitif, afektif, dan psikomotorik dengan sebaik-baiknya.

Sejalan dengan pendapat diatas, Sofo (2004:123) mengemukakan "a competency is composed of skill, knowledge, and attitude, but in particular the consistent applications of those skill, knowledge, and attitude to the standard of performance required in employment". Dengan kata lain kompetensi tidak hanya mengandung pengetahuan, keterampilan dan sikap, namun yang penting adalah penerapan dari pengetahuan, keterampilan, dan sikap yang diperlukan tersebut dalam pekerjaan.

Spencer \& Spencer (2003:9) mengatakan "Competency is underlying characteristic of an individual that is causally related to criterion-reference effective and/or superior performance in a job or situation". Jadi kompetensi adalah karakteristik dasar seseorang yang berkaitan dengan kinerja berkriteria efektif dan atau unggul dalam suatu pekerjaan dan situasi tertentu. Kompetensi merupakan sesuatu yang berkaitan dengan nilai, standar pandangan hidup dan kehidupan, serta mengkait kepada diri sendiri serta orang-orang lain disekitarnya.

Dari berbagai disiplin ilmu maupun dari para peneliti memberikan definisi mengenai kompetensi dengan ungkapan bahasa yang berbeda-beda, namun makna yang terkandung dalam ungkapan itu pada hakekatnya sama. Yaitu kompetensi merupakan karakteristik pribadi seseorang yang menyangkut fungsi, peran, tugas, keterampilan, kemampuan atau sifatsifat pribadi seseorang, yang mendasari seseorang untuk mampu menunjukkan suatu prestasi kerja yang baik dalam bidang pekerjaan, peran dan situasi tertentu.

Untuk mengukur kemampuan guru sebagai sumber daya pegawai birokrasi, dalam penelitian ini peneliti mengunakan konsep Suradinata (2002:17), yang memiliki empat dimensi, yaitu: Keahlian/ kepakaran, Ketrampilan, Pengalaman dan Sikap mental. Dimensi Keahlian/ Kepakaran, dengan indikator: 1) Memiliki keahlian sesuai dengan bidang tugas pelayanan pendidikan; 2) Memiliki kemampuan teknis dalam tugas pelayanan pendidikan; 3) Memiliki pemahaman tentang tugas pelayanan pendidikan; 4) Memiliki kemampuan menggunakan peralatan pendidikan. Dimensi Keterampilan, dengan indikator: 1) Memiliki kemampuan dalam perencanaan; 2) Memiliki kemampuan dalam berkomunikasi; 3) Memiliki kesempatan mengikuti pelatihan/ kursus. Dimensi Pengalaman, dengan indikator: 1) Memiliki pengalaman dalam memenuhi karirnya; 2) Memiliki pengalaman dalam pelayanan pendidikan; 3) Memiliki masa kerja golongan yang memadai dalam menjalankan tugas pelayanan; 4) Memiliki masa kerja pengabdian kepada masyarakat. Dimensi Sikap Mental, dengan indikator: 1) Memiliki tanggungjawab dalam tugas pelayanan; 2) Memiliki perhatian 
dalam melayani pelanggan; 3) Adanya ketaatan terhadap peraturan dalam menjalankan tugas pelayanan; 4) Adanya semangat pengabdian.

Perilaku pada hakikatnya merupakan fungsi interaksi antara seseorang dengan lingkungannya (Thoha, 2002:184). Interaksi tersebut melibatkan kepribadian manusia yang kompleks dengan lingkungannya yang memiliki tatanan tertentu. Proses terjadinya perilaku, pada umumnya timbul karena rangsangan lingkungan-nya, sehingga perilaku manusia memiliki sifat yang berbeda. Perbedaan tersebut disebabkan oleh adanya kemampuan, kebutuhan, cara berpikir untuk menentukan pilihan, pengalaman dan reaksi terhadap sesuatu. Ini adalah formula psikologis, dan mempunyai kandungan pengertian bahwa perilaku seseorang (aparat) itu tidak hanya ditentukan oleh dirinya sendiri, melainkan ditentukan sampai seberapa jauh interaksi antara dirinya dengan lingkungannya.

Perilaku birokrasi pada hakekatnya merupakan hasil interaksi antara individu-individu dengan organisasinya. Oleh karena itu untuk memahami perilaku birokrasi sebaiknya diketahui terlebih dahulu individu-individu yang mendukung organisasi itu. Individu membawa kedalam tatanan birokrasi, kemampuan, kepercayaan pribadi, pengharapan, kebutuhan, dan pengalaman, dan sebagainya. Ini semua merupakan karakteristik individu, dan karakteristik ini akan memasuki lingkungan baru, misalnya birokrasi. Adapun birokrasi yang dipergunakan sebagai suatu sistem untuk merasionalkan organisasi itu juga mempunyai karakteristik sendiri. Jika karakteristik individu berinteraksi dengan karakteristik birokrasi tersebut, maka timbulah perilaku birokrasi. Model umumnya dapat digambarkan sebagai berikut:

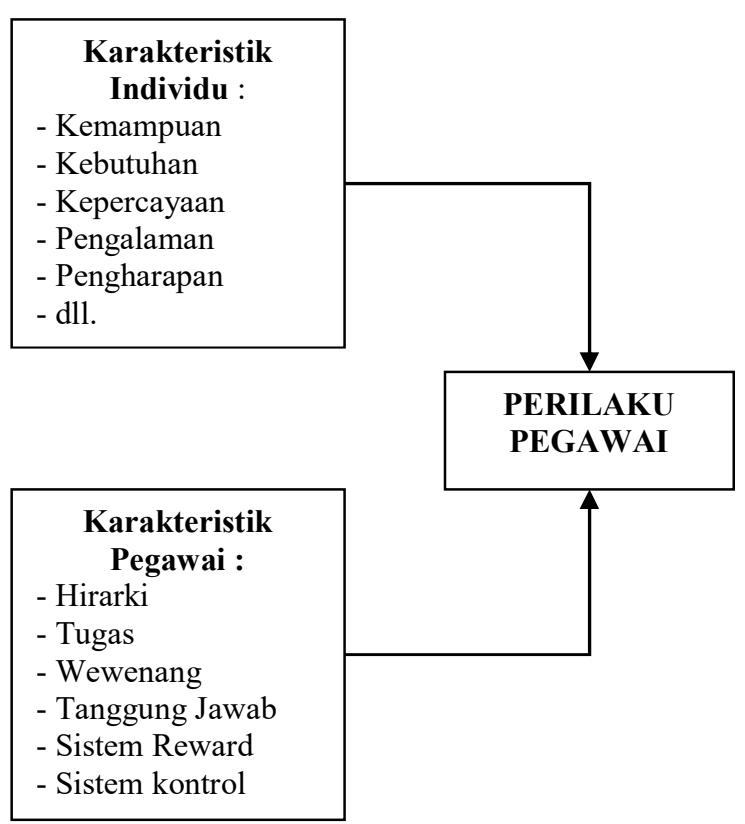

Gambar 1: Model Umum Perilaku Pegawai

Sumber : Thoha (2002:185)

Dari Gambar 1, dapat diketahui bahwa salah satu faktor yang ada dalam diri individu yang mempengaruhi perilakunya adalah kebutuhan seseorang itu sendiri. Setiap individu mempunyai kebutuhan yang berbeda satu sama lain, bahkan pada diri seseorang individu itupun kebutuhan-nya berbeda dari satu waktu kewaktu lainnya.

Untuk mengukur perilaku Perilaku Pegawai, dalam penelitian ini peneliti menggunakan konsep Ndraha (2003:522), yang memiliki tiga dimensi, yaitu: Ketaatan, Tanggungjawab, dan Kedisiplinan. Dimensi Ketaatan, dengan indikator: 
1) Kemampuan mala-yani tanpa membedakan status sosial dan bentuk diskriminasi lainnya; 2) Kemampuan memahami prosedur kerja yang sudah ditetapkan; 3) Objektif dalam memberikan keterangan mengenai prosedur pelayanan; 4) Memungut biaya yang sama bagi setiap masyarakat. Dimensi Tanggungjawab, dengan indikator: 1) Memahami visi dam misi organisasi; 2) Menyelesaikan pekerjaan dengan tanggungjawab, tanpa menunda; 3) Melaksa-nakan tugas pelayanan sampai tuntas tanpa menunda; 4) Kesungguhan melaksana-kan tugas. Dimensi Kedisiplinan, dengan indikator: 1) Kedisiplinan datang tepat waktu; 2) Keberadaan dan kesediaan melayani masyarakat; 3) Kepatuhan dalam melakukan tugas; 4) Kesediaan menerima kritik dan saran.

\section{B. Metode Penelitian}

Penelitian ini dilakukan untuk menganalisis hubungan variabel Kemampuan Guru $\left(\mathrm{X}_{1}\right)$ dan Perilaku Guru $\left(\mathrm{X}_{2}\right)$ dengan Kualitas Pelayanan Pendidikan (Y) pada Sekolah Dasar Negeri. Penelitian ini menggunakan penelitian korelasional. Menurut Riyanto (2010:34), "penelitian korelasi-onal adalah penelitian yang akan melihat hubungan antara variabel atau beberapa variabel dengan variabel lain". Menurut Riyanto (2010: 34), "ciri-ciri dari penelitian korelasional adalah 1) Menghubungkan dua variabel atau lebih; 2) Besarnya hubungan didasar-kan pada koefisien korelasi; 3) Dalam penelitian melihat hubungan tidak dilakukan manipulasi; 4) Datanya bersifat kuanti-tatif".
Populasi pada penelitian ini adalah seluruh guru sekolah dasar di Kecamatan Gabus Wetan Kabupaten Indramayu, yang berjumlah 278 orang. Pengambilan sampel menggunakan Arikunto (2002:120), yaitu "untuk sekedar ancar-ancar maka apabila subjeknya kurang dari 100 lebih baik diambil semua sehingga penelitiannya merupakan penelitian populasi. Selanjutnya jika subjeknya besar dapat diambil antara $10 \%-15 \%$ atau 20-25\%". Berdasarkan pendapat Arikunto tersebut, karena jumlah anggota populasi dalam penelitian ini sebanyak 278 orang, maka ukuran sampelnya diambil sebesar $10 \%$ $15 \%$ atau sekitar $14 \%$ dari 278 orang, yaitu 40 orang sebagai responden, sehingga penelitian ini merupakan penelitian sampel.

\section{Hasil Penelitian dan Pembahasan}

Dari hasil penyeleksian diperoleh kesimpulan bahwa angket yang disebarkan sebanyak 40 angket terkumpul kembali semuanya. Angket yang terkumpul memenuhi ketentuan yang ditetapkan sehingga memung-kinkan data diolah lebih lanjut pada tahap berikutnya.

a. Tabulasi Data

Kegiatan ini merupakan pemberian skor pada setiap alternatif jawaban yaitu diberikan oleh responden sesuai dengan bobot yang telah ditetapkan. Setiap pernyataan dalam ketiga variabel memiliki 5 kriteria jawaban dengan pemberian skor dimulai dari 1, 2, 3, 4, dan 5. Ketentuan untuk pernyataan yang dihitung dengan perhitungan deskriptif sebagai berikut: 1) Variabel Kemampuan Guru $\left(X_{1}\right)$ 
Kriteria interpretasi skor variabel kemampuan guru setingkat $60,47 \%$ tergolong tinggi yang dapat digambarkan, sebagai berikut:

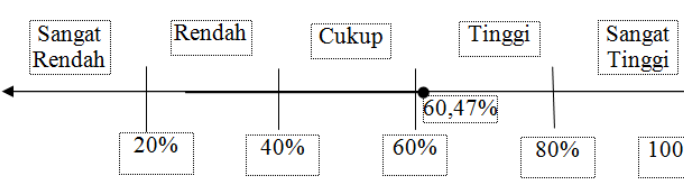

Gambar 2: Kedudukan Variabel $\mathrm{X}_{1}$ Dalam Kontinum

2) Variabel Perilaku Guru $\left(X_{2}\right)$

Kriteria interpretasi skor variabel perilaku guru setingkat 59,5\% tergolong cukup yang dapat digambarkan, sebagai berikut: signifikansi lebih kecil dari 0,05, maka hipotesis diterima. Adapun hasil pengujian hipotesis tersebut adalah sebagai berikut:

Tabel 1: Uji (t) Variabel $\mathrm{X}_{1}$ terhadap $Y$

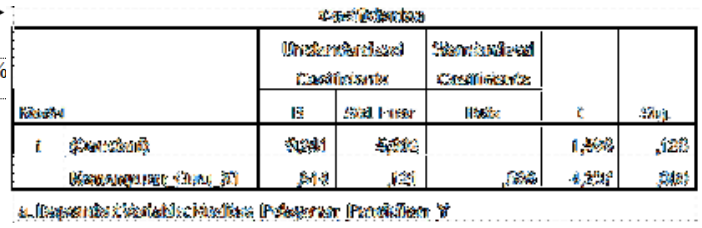

Berdasarkan tabel hasil uji $t$

diperoleh bahwa nilai thitung variabel kemampuan guru $\left(X_{1}\right)$ memiliki nilai sebesar $p$-value 0,000 0,05 artinya berdistribusi signifikan. Hal tersebut berarti kemampuan guru $\left(X_{1}\right)$ secara parsial berpengaruh terhadap

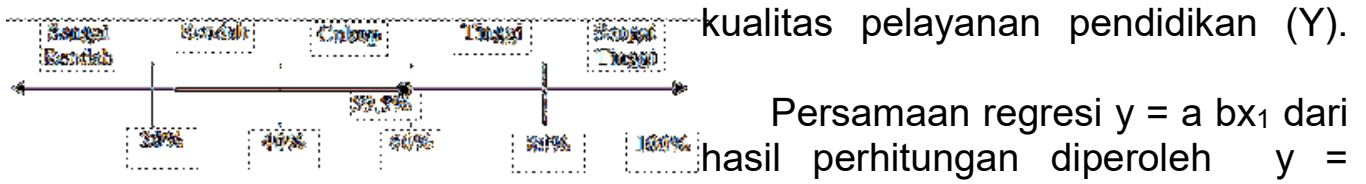
Gambar 3: Kedudukan Variabel $\mathrm{X}_{2}$ Dalam Kontinum

3) Variabel Kualitas Pelayanan Pendidikan (Y)

Kriteria interpretasi skor variabel kualitas pelayanan pendidikan setingkat 56,83\% tergolong cukup yang dapat digambarkan, sebagai berikut:

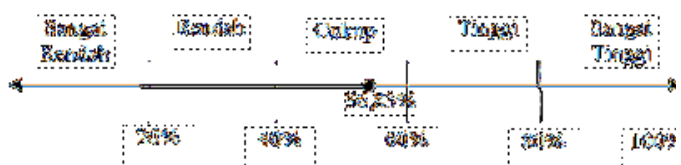

Gambar 4: Kedudukan Variabel $Y$ Dalam Kontinum

Untuk mengetahui besarnya pengaruh kemampuan guru $\left(\mathrm{X}_{1}\right)$ secara individual (parsial) terhadap kualitas pelayanan pendidikan ( $Y$ ) dapat dilihat dari nilai $t$ pada tabel Coefficients dibawah ini dengan kriteria pengujian jika tingkat
$9,241+0,514 X_{1}$. Konstanta sebesar 9,241 menyatakan bahwa jika ada kenaikan nilai dari variabel kemampuan guru $\left(\mathrm{X}_{1}\right)$, maka kualitas pelayanan pendidikan ( $Y$ ) adalah 9,241 . Koefesien regresi sebesar 0,514 menyatakan bahwa setiap perubahan satu skor atau nilai kemampuan guru akan memberikan skor 0,514.

Uji $F$ untuk menguji signifikansi konstanta dan variabel dependen (kualitas pelayanan pendidikan). Dasar pengambilan keputusan yaitu dengan membandingkan $F$ hitung dengan nilai $F$ table. Jika nilai signifikansi < 0,05, maka Ho ditolak artinya koefesien regresi signifikan, dan sebaliknya. Hasil uji $F$ diperoleh data sebagai berikut: 
Tabel 2: Signifikansi Pengaruh Variabel $\mathrm{X}_{1}$ Terhadap $\mathrm{Y}$ hasil pengujian hipotesis tersebut adalah sebagai berikut:

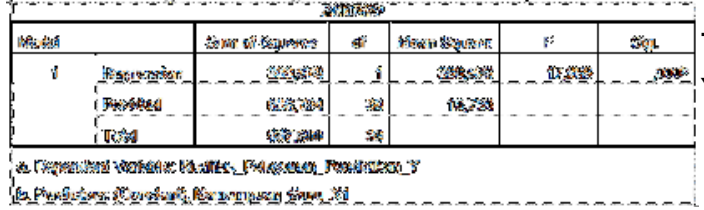

Berdasarkan tabel hasil anova atau $F$ test didapat $F_{\text {hitung }}$ sebesar 17,956 dan nilai signifikansi $0,000<0,05$. Dengan demikian $\mathrm{H}_{\mathrm{o}}$ ditolak artinya pengaruh kemampuan guru terhadap kualitas pelayanan pendidikan pada SD Negeri adalah signifikan.

Selanjutnya untuk mengetahui seberapa besar pengaruh kemampuan guru terhadap kualitas pelayanan pendidikan dapat dilihat dari hasil perhitungan koefesien determinasi pada tabel dibawah ini:

Tabel 3: Besaran Pengaruh Variabel $\mathrm{X}_{1}$ Terhadap $\mathrm{Y}$

Model Summary

\begin{tabular}{|c|r|r|r|r|}
\hline \multicolumn{7}{|c|}{ Model Summary } \\
\hline 1 & $R$ & R Square & $\begin{array}{c}\text { Adjusted R } \\
\text { Square }\end{array}$ & $\begin{array}{c}\text { Std. Error of the } \\
\text { Estimate }\end{array}$ \\
\hline 1 &, $566^{\mathrm{a}}$ &, 321 & &, 303 \\
4,093 \\
\hline
\end{tabular}

a. Predictors: (Constant), Kemampuan_Guru_X1

Dari tabel di atas terlihat bahwa $R$ Square sebesar 0,321 , hal ini berarti bahwa $32,1 \%$ kualitas pelayanan pendidikan dipengaruhi oleh variabel kemampuan guru, sedangkan sisanya $67,9 \%$ dipengaruhi oleh faktor lain yang tidak diteliti.

Untuk mengetahui besarnya pengaruh perilaku guru $\left(X_{2}\right)$ secara individual (parsial) terhadap kualitas pelayanan pendidikan $(Y)$ dapat dilihat dari nilai $t$ pada tabel Coefficients dibawah ini dengan kriteria pengujian jika tingkat signifikansi lebih kecil dari 0,05, maka hipotesis diterima. Adapun

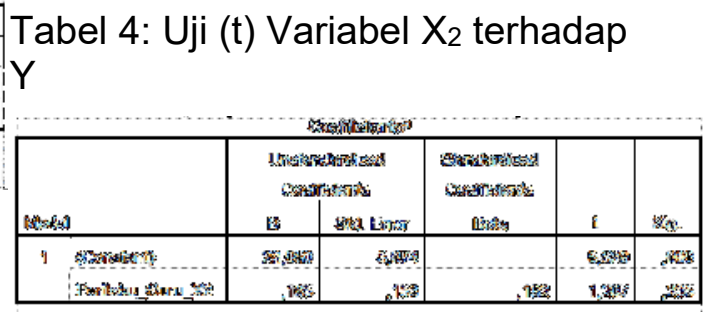

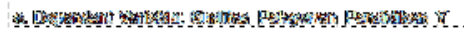

Berdasarkan tabel hasil uji $t$ diperoleh bahwa nilai thitung variabel perilaku guru $\left(X_{2}\right)$ memiliki nilai sebesar $p$-value $0,000>0,05$ artinya signifikan. Dengan demikian perilaku guru $\left(\mathrm{X}_{2}\right)$ secara parsial berpengaruh terhadap kualitas pelayanan pendidikan (Y). Persamaan regresi y $=\mathrm{a} \mathrm{bx}_{2}$ dari hasil perhitungan diperoleh $y=28,050+0,185 \mathrm{X}_{2}$. Konstanta sebesar 28,050 menyatakan bahwa jika ada kenaikan nilai dari variabel perilaku guru $\left(\mathrm{X}_{2}\right)$, maka kualitas pelayanan pendidikan (Y) adalah 28,050. Koefesien regresi sebesar 0,185 menyatakan bahwa setiap perubahan satu skor atau perilaku guru akan memberikan skor 0,185.

Uji $F$ untuk menguji signifikan konstanta dan variabel dependen (kualitas pelayanan pendidikan) diperoleh hasil sebagai berikut:

Tabel 5: Signifikansi Pengaruh Variabel $\mathrm{X}_{2}$ Terhadap $\mathrm{Y}$

\begin{tabular}{|c|c|c|c|c|c|c|}
\hline \multicolumn{7}{|c|}{ Pationtse } \\
\hline neste & & 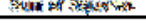 & 6 & 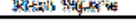 & 8 & $\Psi_{3}$ \\
\hline & Worestare & 政乎 & $i$ & Grex: & 1. A A ASES & 酎 \\
\hline & 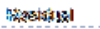 & stencea & ax & 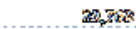 & & \\
\hline & 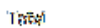 & was & $\sin$ & & & \\
\hline
\end{tabular}

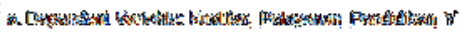

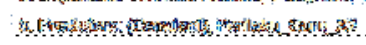

Berdasarkan tabel hasil uji anova atau $F$ test didapat $F_{\text {hitung }}$ 
sebesar 1,456 dan signifikansi 0,235 $>0,05$ sehingga $\mathrm{H}_{\mathrm{o}}$ ditolak artinya pengaruh perilaku guru terhadap kualitas pelayanan pendidikan pada SD Negeri adalah kurang signifikan.

Selanjutnya untuk mengetahui seberapa besar pengaruh perilaku guru terhadap kualitas pelayanan pendidikan dapat dilihat dari hasil perhitungan koefesien determinasi pada tabel dibawah ini:

Tabel 6: Besaran Pengaruh Variabel $\mathrm{X}_{2}$ Terhadap $\mathrm{Y}$

\begin{tabular}{|c|c|c|c|c|}
\hline Model & $\mathrm{R}$ & R Square & $\begin{array}{c}\text { Adjusted R } \\
\text { Square } \\
\end{array}$ & $\begin{array}{l}\text { Std. Error of the } \\
\text { Estimate }\end{array}$ \\
\hline 1 & $192^{\mathrm{a}}$ & 037 & 012 & 4,875 \\
\hline
\end{tabular}

Dari tabel di atas terlihat bahwa $R$ Square sebesar 0,037 , hal ini berarti bahwa $3,7 \%$ kualitas pelayanan pendidikan dipengaruhi oleh variabel perilaku guru, sedangkan sisanya 96,3 \% dipengaruhi oleh faktor lain yang tidak diteliti.

Untuk mengetahui besarnya pengaruh kemampuan guru $\left(\mathrm{X}_{1}\right)$ dan perilaku guru secara bersama-sama (ganda) terhadap kualitas pelayanan pendidikan $(Y)$ dapat dilihat dari nilai t pada tabel Coefficients dibawah ini dengan kriteria pengujian jika tingkat signifikansi lebih kecil dari 0,05, maka hipotesis diterima. Adapun hasil pengujian hipotesis tersebut adalah sebagai berikut:

Tabel 7: Uji (t) Variabel $\mathrm{X}_{1}$ dan $\mathrm{X}_{2}$ terhadap $Y$
Berdasarkan tabel hasil uji $t$ diper-oleh bahwa nilai thitung variabel kemampuan guru $\left(X_{1}\right)$ dan perilaku guru $\left(\mathrm{X}_{2}\right)$ secara bersama-sama (simultan) memiliki nilai sebesar $p$ value $0,000<0,05$ artinya signifikan. Dengan demikian kemampuan guru $\left(X_{1}\right)$ dan perilaku guru $\left(X_{2}\right)$ secara bersama-sama

berpengaruh terhadap kualitas pelayanan pendidikan (Y).

Untuk mengetahui persamaan regresi dapat dilihat dari tabel di atas. Berdasarkan tabel tersebut menunjukkan persamaan regresi linier ganda: $\hat{Y}=7,705+0,500 X_{1}+$ $0,068 X_{2}$. Persamaan tersebut menyatakan bahwa setiap penambahan $X_{1}$ dan $X_{2}$ sebesar 1 maka akan meningkatkan $Y$ sebesar 0,500 dan 0,068, artinya setiap peningkatan kemampuan guru dan perilaku guru sebesar 1, akan meningkatkan kualitas pelayanan pendidikan sebesar 0,500 dan 0,068 .

Dari uji $F$ untuk menguji signifikan konstanta dan variabel dependen (kualitas pelayanan pendidikan) diperoleh data sebagai berikut:

Tabel 8: Signifikansi Pengaruh Variabel $\mathrm{X}_{1}$ dan $\mathrm{X}_{2}$ terhadap Y

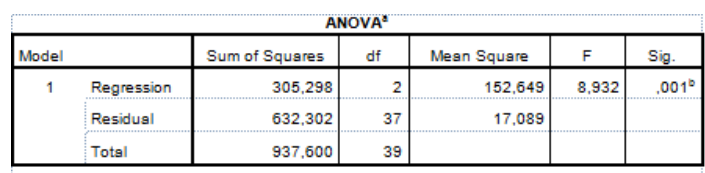

a. Dependent Variable: Kualitas_Pelayanan_Pendidikan_Y

b. Predictors: (Constant), Perlaku Guru $X 2$, Kemampuan Guru $X_{1}$

Berdasarkan tabel hasil uji anova atau $F$ test didapat $F_{\text {hitung }}$ sebesar 8,932 dan signifikansi 0,001 ) 0,05 sehingga $\mathrm{H}_{\mathrm{o}}$ diterima artinya pengaruh kemampuan guru dan perilaku guru secara simultan 
terhadap kualitas pelayanan pendidikan pada SD Negeri adalah signifikan.

Selanjutnya untuk mengetahui besaran pengaruh kemampuan guru dan perilaku guru secara simultan terhadap kualitas pelayanan pendidikan dapat dilihat dari hasil perhitungan koefesien determinasi pada tabel dibawah ini:

Tabel 9: Besaran Pengaruh Variabel $\mathrm{X}_{1}$ dan $\mathrm{X}_{2}$ terhadap $\mathrm{Y}$

\begin{tabular}{|c|r|r|r|c|}
\hline & & & \multicolumn{4}{|c|}{ Model Summary } \\
Model & $\mathrm{R}$ & $\mathrm{R}$ Square & $\begin{array}{c}\text { Adjust R } \\
\text { Square }\end{array}$ & $\begin{array}{c}\text { Std. Error of the } \\
\text { Estimate }\end{array}$ \\
\hline 1 &, $571 \mathrm{~s}$ &, 326 &, 289 & 4,134 \\
\hline
\end{tabular}

a. Predictors: (Constant), Perilaku Guru X2, Kemampuan Guru X1

Dari tabel di atas terlihat bahwa $R$ Square sebesar 0,326, hal ini berarti bahwa 32,6 \% kualitas pelayanan pendidikan dipengaruhi oleh variabel kemampuan guru dan perilaku guru secara simultan, sedangkan sisanya $67,4 \%$ dipengaruhi faktor lain yang tidak diteliti.

Berdasarkan temuan empirik hasil penelitian ini memberikan beberapa informasi, yaitu:

Kemampuan guru pada SD Negeri memberikan pengaruh terhadap kualitas pelayanan pendidikan, (2) Salah satu cara untuk meningkatkan kualitas pelayanan pendidikan pada SD Negeri adalah dengan meningkatkan kemampuan guru, serta (3) Kontribusi yang diberikan yaitu pengaruh kemampuan guru terhadap kualitas pelayanan pendidikan adalah sebesar $32,1 \%$, sementara sisanya dipengaruhi oleh variabel lain, selain variabel perilaku guru, yang tidak dikaji dalam penelitian ini (epsilon).

Berdasarkan temuan empirik hasil penelitian ini memberikan beberapa informasi, yaitu: (1)
Perilaku guru memberikan pengaruh terhadap kualitas pelayanan pendidikan, (2) Salah satu cara untuk meningkatkan kualitas pelayanan pendidikan adalah dengan meningkatkan/memperbaiki perilaku guru, serta (3) Kontribusi yang diberikan oleh pengaruh perilaku guru terhadap kualitas pelayanan pendidikan adalah sebesar $3,7 \%$, sementara sisanya dipengaruhi oleh variabel lain, selain variabel kemampuan guru, yang tidak dikaji dalam penelitian ini (epsilon).

Berdasarkan temuan empirik hasil penelitian ini memberikan beberapa informasi, yaitu: (1) Pelaksanaan kemampuan guru dan perilaku guru memberikan pengaruh terhadap kualitas pelayanan pendidikan, (2) Salah satu cara untuk meningkatkan kualitas pelayanan pendidikan adalah dengan meningkatkan kemampuan guru dan memperbaiki perilaku guru. (3) Kontribusi yang diberikan oleh kemampuan guru dan perilaku guru secara bersama-sama terhadap kualitas pelayanan pendidikan adalah sebesar $32,6 \%$, sementara sisanya dipengaruhi oleh variabel lain, yang tidak dikaji dalam penelitian ini (epsilon).

\section{Kesimpulan}

Terdapat pengaruh yang positif dan signifikan kemampuan guru terhadap kualitas pelayanan pendidikan. Besarnya pengaruh kemampuan guru terhadap kualitas pelayanan pendidikan adalah 32,1 $\%$.

Terdapat pengaruh yang positif tetapi kurang signifikan perilaku guru terhadap kualitas pelayanan pendidikan Besarnya pengaruh 
perilaku guru terhadap kualitas pelayanan pendidikan adalah $3,7 \%$.

Terdapat pengaruh yang positif dan signifikan kemampuan guru dan perilaku guru secara bersama-sama terhadap kualitas pelayanan Pendidikan. Besarnya pengaruh kemampuan guru dan perilaku guru secara simultan terhadap kualitas pelayanan pendidikan adalah 32,6 $\%$.

signifikan. Oleh karena itu, untuk selalu mempertahankan atau meningkatkan kualitas pelayanan pendidikan yang dapat dimulai dengan meningkatkan kemampuan dan perilaku guru melalui perhatian khusus terhadap kebutuhan dan keinginan konsumen.

\section{DAFTAR PUSTAKA}

Arikunto, Suharsimi. 2002. Prosedur Penelitian Suatu Pendekatan Praktik. Jakarta: Rineka Cipta.

Mulyasa. 2003. Menjadi Kepala Sekolah Professional Dalam Konteks Menyukseskan MBM san KBK. Bandung: PT Remaja Rosdakarya.

Ndraha, Taliziduhu. 2003. Konsep Administrasi dan Administrasi di Indonesia. Jakarta: Bina Aksara.

Riyanto. Y., 2010, Metodologi Penelitian Pendidikan, Surabaya: SIC.

Senge, M. Peter. 2001. The Fifth Disciplin. New Jersey: Chatham House Publishing.

Siagian, Sondang P. 2002. Teori Pengembangan Organisasi. Jakarta: Bumi Aksara.
Sianipar. 2001. Perencanaan Peningkatan Kinerja. Jakarta: LAN-RI.

Sofo, $\quad$ Francisco. 2004, Pengembangan Sumber Daya Manusia, Perspektif Peran dan Pilihan Praktis, Surabaya: Airlangga University Press.

Spencer, Lyle M., Jr. \& Signe M., Spencer. 2003. Competence at Work: Models for Superior Performance. John Wiley \& Sons. Inc.

Suradinata, Ermaya. 2002. Manajemen SDM Orientasi Masa Depan. Bandung : Ramadhan.

Thoha. 2002. Perpektif Perilaku Birokrasi. Dimensi-dimensi Prima Ilmu Administrasi Negara. Jakarta : PT Radja Grafindo Persada.

Zeithaml, Valerie., A.Parasuraman \& Leonard L.Berry. 2002. Delivering Quality Service. Balancing Customer Perceptions and Expectations. New York: The Free Press. 